scandalous things. If you perceive that this man is smitten with you and he takes hold of the cloth which you wear, insult him and say, "You are a dog, you are an animal", then straight off in the middle of the night get out of there.'

Then on that evening, on the day the word is finished, the youth sends his messenger to the girls' kitchen to fetch the girl, and so they do right on every evening. Then when a month has gone by the youth will make payment. They call this payment the-offering-to-the-parents-in-law. Some girls, if they have an inkling of some of the traits of the youth and they do not like them, when he makes the parents-in-law gift they will not consent to go again. They say, 'In that youth's bed it has begun to bite.' Then the people say, 'Ngandi and Ngandi have broken off, but the separation is peaceful.' If it should happen that the youth began to be funny with the girl she will come out of the house and shout insults at the youth so that all the village will hear that that youth is not what he should be.

If the youth is a person indeed he does not wish to do himself despite, and if the girl is of the same mind they may keep up the relationship for a long time. Sometimes it may happen that that which was just ordinary petting may lead them to take the word back to the parents and then it becomes an engagement for marriage, but in that case they may not send for each other any more. If the youth loves some one else and they are mutually agreeable it is permissible that they marry, and so it is with the girl. In many cases they separate and the girl marries some other youth and the youth marries some other girl, and everything is all right, nothing has happened. (Communicated by the Rev. MerLIN W. EnNis who translated the original text of PAULINo GONGA LIAHUKa.)

\title{
Inter-Territorial Language Committee (for Swahili).
}

THrs Committee, which is doing useful work in standardizing Swahili and in promoting vernacular literature, has added to its strength by co-opting non-European members representing their respective territories, Kenya, Tanganyika, Uganda, and Zanzibar.

At its last meeting, which was held in January of this year, the Committee suggested the advisability of a wider policy of language and literacy and asked the Directors of Education to consider means for the provision of literature for adult readers and in that connexion to approach their respective Governments with a view to the production of literature in the major vernaculars of the territory concerned.

The annual Swahili essay competition, inaugurated by the Committee in 1935, is maintained with increasing popularity. The degree of interest in this competition is revealed by the fact that over 500 essays have been submitted.

The number of books and pamphlets submitted to the Committee for 
examination is constantly growing, and the Swahili-English and EnglishSwahili Dictionary which is being published under the auspices of the Committee will soon be available. (From a Report of the Committee, dated I 8 April 1939.)

\section{A Twi Spelling Book}

IN 1927 the script recommended by the Institute was adopted for the Twi language. But this was only a first step and many questions remained unsettled. In most West African languages the question of word division is a difficult problem; compound nouns and verbs or combinations of nouns and verbs are used to a very great extent, and the crucial question is which shall be written as one word, which separately, and which joined by a hyphen. None of the existing books in Twi is consistent in this respect. Two recognized experts of the language, C. A. Akrofi and Dr. E. L. Rapp, therefore undertook to compose a Twi Spelling Book (published by the Government Printing Office at Accra), which contains an extensive vocabulary of simple words, compound words, and grammatical forms written in the way the two authors recommend. The vocabulary is preceded by rules which deal with division of syllables, reduplications and repetitions, transliteration of foreign names, nouns and verbal nouns, and nasalization.

Though the Spelling Book does not provide an answer to every question, especially as far as compound nouns are concerned, it will prove a great help in stabilizing the writing of the language. Any one who has to read examination papers in African languages knows that word division is an unfailing stumbling-block to students. Similar spelling books are urgently needed for other languages in order to enable Africans to write and read their language correctly. The natural way of doing such work seems to be, as has been done in the present case, by the co-operation of a competent African with a competent European. 